\title{
Minority ethnic students and science participation: a qualitative mapping of achievement, aspiration, interest and capital
}

Article

Accepted Version

Wong, B. (2016) Minority ethnic students and science participation: a qualitative mapping of achievement, aspiration, interest and capital. Research in Science Education, 46 (1). pp. 113-127. ISSN 1573-1898 doi:

https://doi.org/10.1007/s11165-015-9466-x Available at https://centaur.reading.ac.uk/69980/

It is advisable to refer to the publisher's version if you intend to cite from the work. See Guidance on citing.

To link to this article DOI: http://dx.doi.org/10.1007/s11165-015-9466-x

Publisher: Springer

All outputs in CentAUR are protected by Intellectual Property Rights law, including copyright law. Copyright and IPR is retained by the creators or other copyright holders. Terms and conditions for use of this material are defined in the End User Agreement. 


\section{CentAUR}

Central Archive at the University of Reading

Reading's research outputs online 


\title{
Minority ethnic students and science participation: A qualitative mapping of achievement, aspiration, interest and capital
}

\section{Billy Wong \\ University of Roehampton, UK, billy.wong@ roehampton.ac.uk}

\begin{abstract}
In the UK, the 'leaky pipeline' metaphor has been used to describe the relationship between ethnicity and science participation. Fewer minority ethnic students continue with science in post-compulsory education and little is known about the ways in which they participate and identify with science, particularly in the secondary school context. Drawing on an exploratory study of 46 interviews and 22 hours of classroom observations with British students (aged 11-14) from Black Caribbean, Bangladeshi, Pakistani, Indian and Chinese ethnic backgrounds, this paper identified five 'types' of science participation among minority ethnic students. The five 'types' of science participation emerged from an analysis of students' science achievement, science aspiration, science interest and science capital. The characteristics of the five 'types' are as follows: Science adverse students have no aspirations toward science and lacked interest, achievement and capital in science. Science intrinsic students have high science aspirations, interest and capital but low science attainment. Students who are science intermediate have some aspirations, interest and capital in science, with average science grades. Science extrinsic students achieve highly in science, have some science capital but lacked science aspirations and/or interest. Science prominent students are high science achievers with science aspirations, high levels of interest and capital in science. The findings highlight that minority ethnic students participate in science in diverse ways. Policy implications are suggested for each 'type' as this paper provides empirical evidence to counter against public (and even some academic) discourses of minority ethnic students as a homogeneous group.
\end{abstract}

Keywords: minority ethnic students, aspiration, diversity, engagement, participation

\section{Introduction}

Science is highly valued in many developed countries, including the UK (HM Treasury 2011). Governments and businesses are concerned that the shortage of skilled professionals in science, technology, engineering and mathematics (STEM) will weaken their country's future knowledge and economic competitiveness (see ACOLA 2013 for Australia; CBI 2012 for UK; National Academy of Sciences 2005 for US). UK data may be sketchy on the supply and demand of STEM graduates, but it is evident that enrolment within STEM education subjects varies significantly by ethnicity, gender, socioeconomic background and educational level (House of Lords 2012; Smith 2011). Minority ethnic students, women and the working class are poorly represented in STEM education, particularly in the physical sciences (Elias et al. 2006; EngineeringUK 2014). In science education, these underrepresented students tend to experience more challenges and difficulties than white middle class men, who are typically the epitome of science (Brickhouse et al. 2000; Ong 2005; Wong forthcoming). While research into gender equity have attracted considerable attention within science education (e.g. Archer et al. 2014a; Blickenstaff 2005; Brotman and Moore 2008; Ceci and Williams 2007), few studies have explored the ways in which minority ethnic young people experience and participate in science (e.g. Marlone and Barabino 2009; Tan and Calabrese Barton 2010), especially in UK secondary school context (e.g. Wong 2012, forthcoming).

UK census data indicate that the minority ethnic population has risen by around $40 \%$ 
between 2001 and 2011, with the figure expected to rise further in the foreseeable future (Jivraj 2012). This means minority ethnic students are likely to make a growing contribution to the STEM talent pool. However, the 'leaky pipeline' metaphor has been used to describe the relationship between ethnicity and science participation (Elias et al. 2006). Existing studies suggest that science achievement and aspirations are important markers of young people's trajectory in science. Minority ethnic students are less likely to study science in postcompulsory education, partly as a result of poor attainment but also due to alternative career choices or studies (ibid.). Tai et al. (2006) found that average mathematics achiever in the US with a science-related career aspirations are more likely to graduate in the physical sciences or engineering than high mathematics achievers without any science career aspirations. Similarly, Riegle-Crumb et al. (2010) found minority ethnic boys (i.e. Black and Hispanic) in the US to have similar science career aspirations as White boys, despite large attainment differences between these students. While low achievement can systematically prevent some students from the further study of science (DIUS 2009), science achievement per se does not necessary hinder science aspirations, since low/er achieving science students have expressed aspirations toward science (DeWitt et al. 2011; Wong 2012). Thus, science achievement and aspirations are central to understanding the ways in which students participate in science. It is important to note that aspirations can be circumscribed by social identities such as class, gender and ethnicity (Archer et al. 2010; 2014b). Studies have found that White (and particular Asian) middle class boys as the most likely social groups to express science aspirations and consider a future in science as thinkable for 'people like me'(Archer et al. 2012; Schreiner and Sjøberg 2007).

More broadly, there are public concerns that young people are lacking interest in science and STEM-related careers (Jenkins and Nelson, 2005). Interest is generally defined as 'the feeling of wanting to know or learn about something or someone' (Oxford Dictionaries 2010) and existing studies suggest that the critical period during which students begin to lose (or form) interest in science occurs between ages 11 and 14 (Bennett and Hogarth 2009; Osborne 2008; Tai et al. 2006). Previous studies suggest that widespread images and discourses of science/scientists as typically for privileged white men can contribute toward the general lack of interest in science for students without these advertised characteristics, particularly minority ethnic students (Losh 2010; Mendick and Moreau 2013; Ong 2005). However, the relationships between science interest and science achievement or aspirations remains ambiguous, as students with limited interest in science (e.g. in or out of school) can also strive for high science achievement or have aspirations toward science-related careers due to the extrinsic (and exchange) value of the subject (i.e. science), such as for university application or future employment (Brickhouse and Potter 2001; Gungor et al. 2007; Wong 2012).

Aschbacher et al. (2010) also noted that higher science achievers tend to be from more affluent families, with access to a wide range of economic, social and cultural resources to support science achievement. These resources can be read as science capital, which have 'the potential to generate use or exchange value for individuals or groups to support and enhance their attainment, engagement and/or participation in science' (Archer et al. 2014a: 5). For instance, economic capital could be used to increase science capital through the purchase of resources or opportunities (e.g. science tutoring, visits or equipment). Social capital includes social networks and contacts with people who may work in, or possess knowledge of, science education and careers. Cultural capital refers to 'qualifications, enduring habits/dispositions' and an understanding of the 'rules of the game' within the enterprise of science (ibid.). The importance of science capital in students' decision to study post-compulsory science was investigated by Lyons (2006) in the context of Australian students (age 15-16). Lyons found students who enrolled in advanced physics tend to have family members with science-related 
cultural and social capital, such as parents with extensive knowledge in, or experiences of, science and science-related careers (see also Ho 2010 for Hong Kong students).

Although there are many factors which can shape young people's experiences of science, the influences of achievement, aspirations, interest and/or capital in science appear significant. As such, informed by these four markers, this article seeks to foreground the diverse experiences of minority ethnic students in science by presenting five 'types' of science participation. Each 'type' groups together similar experiences of science, based around the four markers. It is important to stress that the use of 'types' is intended to illustrate the diverse ways of science participation and that students' own relationship with science can change and develop over time. The characteristics of the five 'types' are as follows: Science adverse students have no aspirations toward science and lacked interest, achievement and capital in science. Science intrinsic students have high science aspirations, interest and capital but low science attainment. Students who are science intermediate have some aspirations, interest and capital in science, with average science grades. Science extrinsic students achieve highly in science, have some science capital but with no science aspirations and/or interest. Science prominent students are high science achievers with science aspirations, high levels of interest and capital in science. The purpose here is not to present a 'directory' of science participation, nor to suggest that (particular groups of) minority ethnic students necessarily take part in science in these specific ways. Rather, this study aims to provide a more nuanced exploration of the multiple ways in which minority ethnic students can interact with, and be involved in, science. The five 'types' are meant to be indicative of the possible ways in which students can participate in science, which can also be shaped by social inequalities of ethnicity, class and gender. This paper provides empirical evidence to counter against public (and even some academic) discourses of minority ethnic students as a homogeneous group, particularly in science education. Implications for policy are suggested in light of the different 'types' of science participation.

\section{The study}

This paper draws on data from an exploratory qualitative study which investigated the science and career aspirations of minority ethnic students (aged 11-14) in London, England, in response to concerns that young people are disengaging from science during the early phase of secondary education (Osborne 2008). Forty-six semi-structured interviews were conducted with British students from Black Caribbean (five boys, four girls), Bangladeshi (eight boys, one girl), Pakistani (two boys, three girls), Indian (four boys, six girls) and Chinese (seven boys, six girls) backgrounds. Field notes from science classroom observations (22 hours) are included as supplementary research data, which observed the interactions of participating students. A pragmatic approach was adopted for classroom observation and 16 students were observed. Other students were not observed due to timetable clashes and practical issues.

Students were recruited from seven London schools, in boroughs known to have a higher population of (particular) minority ethnic groups, which comprised of four state coeducational schools ('Barton School', 'Cranberry School', 'Davidson School' and 'Everest School') and three Chinese complementary schools ('Hakka School', 'Lancang School' and 'Yangtze School'). Students were invited to participate through an information letter and consent form addressed to their parents, which were distributed by gatekeepers (e.g. school teachers) to students whom they had identified as eligible (i.e. as matching the age and ethnicity criteria). These criteria were later clarified with students, who were asked to selfascribe an ethnic (or cultural) identity. Minority ethnic students were not equally recruited from each school because some groups, such as Chinese students, were poorly (or even not) 
represented at the state schools which agreed to participate. Only two Chinese students were recruited from state schools. Hence, three Chinese complementary schools in London were recruited through personal contacts, which yielded eleven more Chinese participants.

As a general indication, the four state schools were ethnically diverse, had average or slightly above average in terms of economically deprived students, and were 'typical' (e.g. all within $15 \%$ of the average) in their respective local authority in terms of achievement. Chinese students recruited from complementary schools all attended state secondary schools that were slightly 'above average' in achievements within their respective local authorities. The majority of minority ethnic students in the study are considered as 'working class' $(n=39)$, with seven from 'middle class' backgrounds, which is taken to have at least one university educated parent, in a professional occupation. As such, most 'working class' students said that their parent/s were educated up to college level, with routine or semiroutine occupations. A gender balance was generally achieved within each minority ethnic group, apart from Bangladeshi students (see earlier; in total, 26 boys and 20 girls).

Interviews lasted 40 minutes on average and were later transcribed verbatim, with student names anonymised. Students were individually interviewed on issues around their views and experiences of science, both inside and outside of school, as well as their current grades in, and aspirations toward, science. Interview transcripts were initially organised and coded using NVivo by emerging concepts and themes, as the author move 'back and forth' between the data and analyses in an iterative process through which the dimensions of themes are refined and/or expanded through the comparison of data (Miles and Huberman 1994). Informed by the literature, the themes around science achievement, aspirations, interest and capital were then analysed as discourses/“markers' of science participation, which began with a qualitative mapping of relevant data into a nested table and created a matrix of data within and across these markers.

Science achievement includes students' recent science grade, which is also assessed in relation to the expected grade of students in their respective age group, as set out in official documents (see DfE 2010). For example, students may be below average, average or above average. Students' grades were self-reported but confirmed by teachers where possible. Most students reported similar grades across science, maths and English. Science aspiration focuses on students' future career ambitions, which were grouped as science-related and nonscience-related ${ }^{1}$. Science interest considers the general views of students toward science, such as their likes and dislikes about science. Here, an interpretative but systematic judgement is made in relation to the ways in which students articulated their science interest, both in and out of school. Students were grouped into 'high', 'medium' and 'low' science interest. 'High' science interest includes students who voiced a range of positive views or engagements across formal (e.g. in the classroom) and informal science (e.g. at home). 'Medium' science interest refers to students with positive but also negative opinions of science in and/or out of school and 'low' science interest means students have little or no enthusiasm toward science in and out of school. Science capital refers to science-related resources students are able to draw upon in their associations with science, focusing on the dimensions of economic, social and cultural capital (Archer et al. 2012). Similar to science interest, students were tentatively grouped into 'high', 'medium' and 'low' science capital. Students considered to have access to three forms of capital related to science (i.e. economic, social and cultural) were

\footnotetext{
1 This study grouped the following occupations, which was mentioned by students themselves when asked of their career aspirations, as being science-related: scientist, doctor, dentist, paediatrician, veterinarian, pharmacist, engineer, architect, pilot, inventor, computer programmer and electrician. All other careers suggested by students, which included ambitions to be a lawyer, banker, accountant, artist, teacher, sportsperson, 'in the show business' and 'in business', were grouped as non-science-related professions (see Royal Society 2014; US Census Bureau, 2011; Wong forthcoming).
} 
categorised as 'high', those with two forms of capital were 'medium' and students with just one form of science capital (or none) were considered as 'low'2. Using the nested table, students with similar experiences of science were then grouped and explored as clusters, even though students within each cluster may have individual (minor) variations. Each cluster (formed by the abovementioned four markers) was interpreted as a distinctive 'type' of science participation. This study identified five prevalent clusters, or 'types', of science participation which encapsulates the different ways in which minority ethnic students' construct their relationships with science.

\section{A mapping of science participation}

Participation is defined as 'the action of taking part in something' (Oxford Dictionaries 2010), which can refer to how individuals become involved in something or with someone, such as science/scientist. In the current study, science participation 'types' are empirically informed through science achievement, aspirations, interest and capital (see Table 1 for summary). The characteristics of each 'type' are discussed below and particular attention is paid to the social identities (e.g. of ethnicity, gender and class) of students who narrate these scientific practices. Although minority ethnic students, as a group, appear to populate certain 'types' of science participation, this may reflect the qualitative nature of the study. Indeed, students from a range of social backgrounds (e.g. ethnicity, gender and class) are represented across the different types of science participation. It is important to restate that these 'types' are neither fixed nor rigid. The five 'types' of science participation are intended as a means for 'mapping out' the various ways minority ethnic students take part in science.

Table 1: 'Types' of science participation

\begin{tabular}{l|l}
\hline \multicolumn{1}{c|}{ 'Types' } & \multicolumn{1}{c}{ Brief description } \\
\hline Science adverse & $\begin{array}{l}\text { Students express no science career aspirations and have with } \\
\text { low achievement, interest and capital in science. (N=9, } \\
\text { mostly Black Caribbean boys and girls) }\end{array}$ \\
\hline Science intrinsic & $\begin{array}{l}\text { Students express science career aspirations and have } \\
\text { indicated some levels of science interest or capital, but low } \\
\text { achievement in science. (N=8, mostly Bangladeshi boys) }\end{array}$ \\
\hline Science intermediate & $\begin{array}{l}\text { Students express at least one science career aspiration, with } \\
\text { average achievement, interest and capital in science. (N=6, } \\
\text { students from all five minority ethnic groups represented) }\end{array}$ \\
\hline Science prominent & $\begin{array}{l}\text { Students express no science career aspirations and/or } \\
\text { interest, but have average or above average achievement and } \\
\text { capital in science. (N=13, mostly Chinese boys and girls) }\end{array}$ \\
\hline $\begin{array}{l}\text { Students express science-related career aspirations, with } \\
\text { above average achievement, interest and capital in science. } \\
\text { (N=10, mostly Indian boys and girls) }\end{array}$ \\
\hline
\end{tabular}

\footnotetext{
2 While the categorisations for science interest and science capital seem to favour 'width' over 'depth', discretions can be made for students who particularly excel in some but not all aspects of science interest or capital. For example, students may be categorised as 'high' science capital due to exceptional science-related social and cultural capital, despite limited economic capital.
} 


\section{Science adverse}

Science adverse refers to students with below average levels of achievement, interest and capital in science, and who expressed no aspirations toward science-related careers. In other words, science adverse students have little, if anything, in common with science. Nine students (four boys and five girls) have articulated this 'type', most of whom were working class (8 out of 9) and from Black Caribbean background (5 out of 9). There were one Pakistani (the only 'middle class'), one Bangladeshi and two Chinese students who are science adverse. For example, Gina (Black Caribbean girl, Barton) expressed aspirations to be a policewoman or a football player. She said she could not envision herself working in science and suggested that being a scientist 'wouldn't really be that fun, like working long hours and that ... I don't like it'. She claims to have lost interest in school science since the decline of practical activities and the increase in textbook reading/work at the end of year 7 (i.e. first year of secondary school) (Masnick et al. 2010). She reported below average grades for most of her subjects, including science, when mapped against the national standard of student grades expected of her age (DfE 2010). Although Gina enjoys sports, where she plays football and netball for her school, she appears to have little if any resources in, and exposure to, science outside of school. Gina is considered to be science adverse because she did not have aspirations toward science-related careers and her achievement, interest and capital in science are considered below average/'low'.

As the only middle class student who is science adverse, Amy (Pakistani girl, Barton) wants to be a fashion designer. Unlike most other students in this study, who reported similar attainment across the 'core' subjects, Amy had below average grades for science but above/average grades for English/maths. Her low achievement in science may reflect her lack of science interest (Ainley and Ainley 2011). Amy bemoaned that in science classrooms 'we did bookwork every single lesson ... for the whole week, which was boring'. Her apparent lack of interest in science was also noted in classroom observation:

Ms Smith [science teacher] gives out a small task for students on the smartboard. Amy joins in a conversation with two other girls at her table, switching her body position completely with her back facing Ms Smith and the smartboard. There were moments of laughter from the trio, with Amy leaning back and forth, looking engaged in the conversation, but not on the task.

Amy appears to have access to science-related media at home, in the form of subscription television (e.g. the Discovery Channel), even though she said it was 'boring'. Here, Amy underutilises the science capital that could be available to her. The presence of Chinese students who are science adverse may also be seen as a surprise, since collectively they excel in (science) education (Elias et al. 2006). Yet, two Chinese students in the current study shared views and experiences of science as Gina. For instance, Harry (Chinese boy, Everest) is in the lowest ability group for science and admitted that he 'don't really like science that much' and has non-science-related career aspirations to be 'a chef or badminton coach'. While working class Black Caribbean students are more likely to be science adverse in this study, students from other class and minority ethnic backgrounds can also articulate such similar views and practices toward science.

\section{Science intrinsic}

Students who are science intrinsic have aspirations toward a science-related career, with some science capital and interest in science, but below average science achievement. Eight 
students (six boys and two girls) share this 'type', including one middle class Black Caribbean and five working class Bangladeshi boys, as well as one Pakistani and one Chinese working class girl. With below average grades in science (and English and maths), Ralph (Bangladeshi boy, Everest) wants to be a doctor because he likes the idea of 'saving lives'. He enjoys the 'practical we do' in science but complained that 'we have to keep writing it up'. Consistent with Aschbacher et al. (2010), who found low achieving students with science-related career aspirations tend to lack social and cultural capital in science, Ralph said that 'I don't know where to even get them' when asked if he has any 'experiment kits' at home. Ralph is science intrinsic because his aspirations to be a doctor are driven by his interest in, and the application of, scientific knowledge, even though he lacked science capital and has below average grades in science. In other words, his science career aspirations may be idealistic, a position which was also shared by a few other Bangladeshi boys.

Yet, not all low achieving science students are deprived of science capital. Shane (Black Caribbean boy, Barton), the only middle class student in this group, has access to science-related books (e.g. 'Horrible science') and watches children's television science programmes (e.g. 'Brainiac'). Similarly, although Jube (Bangladeshi boy, Barton) is considered a low achiever in science, he has available to him capital related to science. Jube wants to be an engineer and he participates in an afterschool science club, which he found to be 'interesting, you get to like throw bombs, do robots, make stuff, investigate stuff, see in the camera, make rocket and those stuff'. His involvement in the science club can potentially broaden his scientific knowledge and understanding, and deepen/reinforce his science interest or aspirations. Science classroom observation noted the following:

Jube seems like an 'ideal' pupil in terms of behaviour and attitude. He frequently asks questions and is generally focused and engaged throughout the lesson. Jube appears particularly interested in experiments - he continued asking Simon (a trainee teacher) questions during and after an experiment which involved burning metals.

Although few science intrinsic students, such as Shane and Jube, have access to some form of science capital, these resources failed to translate into higher science attainment. Reasons as to why this is the case merits further investigation and existing literature suggests structural and social inequalities (e.g. low teacher expectations) against particular minority ethnic groups (e.g. Black Caribbean and Bangladeshi students) may be partially accountable (Crozier 2009; Gillborn 2008). Thus, science intrinsic students have aspirations toward science-related careers, but their career ambitions may appear unrealistic as they have low grades in science and many lacked science capital or interest.

\section{Science intermediate}

Science intermediate students have science-related career aspirations and science achievement, interest and capital that are categorised as average or medium. Science intermediate is similar to science intrinsic, with the key difference in science attainment, as students who are science intermediate have average and even above average science grades. Six students (four boys and two girls; five working class and one middle class) from all five ethnic backgrounds shared this 'type'. There are two Bangladeshi students and one student from each of the four other minority ethnic groups.

Kyle (Bangladeshi boy, Everest) has average grades in science and he wants to be an artist, mechanic or electrician. He is considered to have some science interest because he 'like[s] doing experiments ... trying to blow things up, its fun' and he even tried a scientific experiment at home ('I heard and tried one thing, which is like, cornflower and water, and 
you mix it and you can squish it becomes like hard thing'). However, he also finds science lessons to be repetitive ('the topics were done, we covered it last year') and excessive in writing ('I don't like every single topic in science ... where you have to write a lot'). Kyle appears to have access to some science capital. He watches science-related television programmes 'because they experiment with like, cars, friction and stuff, it makes it more exciting' and that his mother 'just gives me like these workbooks to read' about science. However, Kyle confessed that 'I haven't looked at it yet' and thus his available science capital was not fully utilised. Kyle, and others like him, are science intermediate because they have science career aspirations and their participations in science seem be in the 'middle' in terms of science achievement, interest and capital.

\section{Science extrinsic}

Science extrinsic refers to students without science-related career aspirations and/or interest but with above average science grades. Students who share this 'type' have some interest and/or capital in science. Thirteen students (six boys and seven girls; 10 working class and three middle class) are grouped as science extrinsic, including one Black Caribbean, one Pakistani, one Bangladesh, three Indian and seven Chinese students. Science extrinsic students excel academically in science despite their lack of aspirations in science-related careers. Here, science extrinsic students may perform in science (through achievement) for reasons other than as preparation for a science career. Students may aspire towards high academic attainments, irrespective of the subject, as a part of their overall goal to accomplish high educational achievements across all disciplines. Recent studies have explored such phenomena through the notions of (gender, class and/or ethnic) performativity and as something 'people like me' do (e.g. Archer and Francis 2007).

Hins (Chinese boy, Yangtze) is a high science achiever and he finds science to be 'quite interesting because it's all about how things work ... what happens and why it happens'. He appears to have access to science capital, particularly from his father, who has a Master's degree in physics ('he became a physician ... he just enjoys science in school and he enjoyed it enough to take it as a, take it to a degree'). However, Hins aspires to be in business and rejects the idea of working in science, claiming 'it's not my kind of thing ... I enjoy it but I don't enjoy it to an extent I want to be a scientist'. He also implied that his interest in science is 'only in school'. Hins, and several Chinese students like him, are science intrinsic because they have above average grades in science but without any science career aspirations. Possible explanations as to why some high achieving minority ethnic students in science find careers in science as undesirable is discussed elsewhere (Wong forthcoming).

A few students who are science extrinsic voiced science-related career aspirations but limited science interest. Samantha (Indian girl, Cranberry) wants to be a doctor and continue with the study of science at the highest level. Yet, Samantha said she is losing interest in science: 'I'm not really interested in it anymore like now when I listen to science lessons and stuff, I find it really boring and I just don't really want to listen'. For Samantha, her choice of future study reflects 'any subjects that will help me in the future that will actually benefit my job and stuff'. She recognises that science subjects can be beneficial for her later educational and careers options ('it can help me in the future and stuff, like good to do that. It's a good qualification'). Samantha's aspirations to be a doctor may also be strengthened by her belief that 'in this country I think there's like a need for doctors'. The apparent contradiction between her pursuit of further science study, despite a lack of interest, could reflect the importance of extrinsic and exchange values of science, particularly as preparation for future employment (Archer et al. 2012; Mujtaba and Reiss 2013; Wong 2012). 


\section{Science prominent}

Science prominent students have science-related career aspirations and tend to command above average achievement, interest and capital in science. Students who articulate this 'type' would appear the most likely to excel and progress in science study and careers. Ten students (five boys and five girls; nine working class and one middle class) are grouped as science prominent, which includes one Black Caribbean, one Pakistani, two Chinese and six Indian students.

Denise (Indian girl, Cranberry) has aspirations to be a medical professional, such as a dentist or doctor and she has above average science grades for students her age. She seems very interested in science ('I like experiments and learning about the human body ... most of it is understandable and you can find and learn most of it') and has available to her a range of science capital. Denise believes that her family is very enthusiastic about, and supportive of, science learning ('my dad likes science [and] my sister's really good at science'). She recalled that 'when I was in primary school, and if I had any homework my sister and dad and mum will help me, and we got lots of science books at home'. Denise said that 'my mum and dad got me this year CJP [educational] books and stuff, in science so I just read, and now they got me Key Stage 3 [age 11-14] ones'. Denise appears to have a supportive family who are actively involved in her education, particularly in science. In a related vein, her parents have also purchased Denise access to private tuition as an additional support to her education, despite coming from a working class background (see Archer and Francis 2007). In relation to her science career aspirations, Denise is aware that 'one of my cousins is going to be a dentist [and] a distant relative, I don't know her name but she is a doctor'.

As can be seen, Denise appears to reside in a 'pro-science' family because science and scientific understanding is strongly embedded and encouraged within the home environment (Archer et al. 2012). She is considered to be science prominent because her career aspirations as a medical professional appear to be well supported by her achievement, interest and capital in science (Aschbacher et al. 2010). Although Indian students appear most likely to be science prominent, it is important to emphasise that the ways in which minority ethnic students participate in science is not specific to social identity locations.

\section{Discussion and implications for policy and practice}

This study builds on a small but growing understanding of how minority ethnic students participate in science, particularly in the UK. Informed by students' achievement, aspirations, interest and capital in science, five 'type' of science participation are identified which demonstrates the diverse experiences of, and approaches to, science among minority ethnic students. Findings from the current study highlight a possible relationship between ethnicity and 'types' of science participation, although such patterns are less apparent by gender or social class.

Students from Black Caribbean background seem most likely to be science adverse, which may reflect their 'early leak' from the science education pipeline (Elias et al. 2006). Black Caribbean students tend to have less in common with science than students from other ethnic groups (see Change et al. 2014 in the US context). Bangladeshi students, particularly boys, dominated those who are science intrinsic. These students have expressed sciencerelated career aspirations despite below average attainment (and available capital) in science. Some students may simply be fascinated by particular science careers, although their aspirations could be malleable, superficial and temporary. The discrepancy between high aspirations in science but low science attainment has previously been explain through the 
'aspiration-achievement paradox' (DeWitt et al. 2011), which posited that these students lacked the know-how to realise their aspirations.

Science intermediate students include students from a range of minority ethnic backgrounds, who have expressed science career aspirations and average science achievement. Chinese students tend to be science extrinsic as many lacked science career aspirations despite achieving highly in science (and other subjects in general). These students seem to recognise the exchange value of science for future study or career options (Mujtaba and Reiss 2013). Many Indian students are science prominent. These students have above average science achievement and science-related career aspirations, as well as high levels of interest and capital in science. In the current study, the likelihood of Chinese and Indian students who are science intrinsic and science prominent seems to mirror their national tendency to excel and participate in post-compulsory science education. At degree level, however, many students (particularly Indian) seem to deviate into science-related degrees, particularly in the medical field (Elias et al. 2006; HESA 2013).

This study calls for a greater awareness within science education research and policy of the differences between minority ethnic students. Recent literature in North America suggest that the science education trajectories of Asian students (e.g. predominantly with Chinese, Japanese or Korean descents) are similar to white students (Adamuti-Trache and Sweet 2014; Chang et al. 2014), whereas Black and Hispanic/Latino students are less likely to persist in STEM education (Cole and Espinoza, 2008; Riegle-Crumb et al. 2010). The 'types' of science participation can provide a useful platform for understanding the diverse ways in which minority ethnic students participate in science in particular ways. These 'types' have illustrated that some students can achieve in science without science interest or aspirations while other students can have science career aspirations despite below average achievement in science. Thus, policy and practice in science education require multiple approaches in order to devise strategies that are appropriate for different types of students.

From the perspective of scientific literacy, there remains a challenge for science policymakers and educators in relation to science adverse students, who seem to have already ruled out science as a field for future study or employment. Students who are grouped in the other 'types' of participation have all expressed or demonstrated some form of positive science participation, either through science-related career aspirations and/or average or higher science achievement. Building on the 'types' of science participation, this paper has three messages for science education which target specific student groups with the aim to enhance their options in science.

\section{Message 1 -Address the 'science aspiration-achievement paradox': Raise attainment}

It is often assumed in policy that low aspirations lead to low achievement and thus the aim of raising aspirations is "to break a perceived link between low aspirations and the lack of educational achievement for students who live in poverty" (St Clair and Benjamin 2011, p. 502). Consistent with DeWitt et al. (2011), the current study has found that aspirations toward science-related careers can operate independently from students' science grades, as in the case of students who are science intrinsic. Young people, even those with below average science grades, do not seem to suffer from a 'poverty of science aspirations'. This calls into question the effectiveness of initiatives that are aimed at raising or broadening the students' aspirations (e.g. AimingHigh in the UK). Instead, this study suggests that science education policies can be usefully reconfigured to focus on how students could realise their aspirations, particularly on raising achievement, rather than raising ambitions. Within schools, this could mean a stronger emphasis on academic competence throughout the learning and teaching of science, to counter against the possible exclusion of interested students from the study of 
further science due to low attainment. For instance, schools that run afterschool or lunchtime science clubs could embed a stronger academic/curriculum focus into their activities, in addition to the promotion and facilitation of scientific interest. Such policies could be particularly beneficial to science enthusiasts such as Jube (who is science intrinsic), who could be barred from studying advanced sciences due to low attainment.

\section{Message 2 - Broaden the pathway into science careers}

Although science intrinsic students lack academic science competence, it is equally important for science educators to conserve, capitalise and build on their existing interest or aspirations in science. Many young people, particularly science intrinsic students, are enthusiastic about practical science. To support their science participation, science interventions could be steered towards the applied elements of scientific skills and practical competences. Science intrinsic students may benefit from further knowledge of the alternative science career options available to students like them, aside from the conventional route of university degrees in science which demand a certain level of academic accreditation, such as apprenticeship or vocational study (Osborne and Dillon, 2008). Science intermediate students can be seen as the 'undecided' group in relation to their trajectories in science education. They have academic potential and/or personal interest in science but tend to have aspirations toward both science and non-science-related careers. Science intermediate students could benefit from workshops or lessons that will broaden their knowledge around science careers. This study suggests that career talks in school could provide students (particularly those who are science intrinsic and science intermediate) with a better understanding of the possible pathways into a range of science careers. With commitment, government or school policy could demand discussions of science careers to be embedded within the science curriculum (Archer et al. 2013). Such an approach could also promote and facilitate a wider range of non-academically oriented 'science identities' and may help to dispel the popular image of science as exclusively for those who are high achievers or clever (Carlone and Johnson 2007; Dewitt et al. 2013).

\section{Message 3 - Retain the scientifically competent in science education}

Science extrinsic students tend to have little or no interest in, or aspirations toward, science, despite their above average achievement in science. Science extrinsic students may attract less attention from policymakers because they appear 'successful' in school science due to their high achievement. However, these students are not immune to leaking from the science education pipeline, although their departure from science may happen at a later stage, such as in higher education (Elias et al. 2006). Although science extrinsic students, such as Hins, are likely to continue with science, at least until it is no longer considered valuable, science educators could target this group of high achievers and work with them to develop ways in which science can be experienced as more enjoyable and approached with intrinsic as well as extrinsic motivation (Mujtaba and Reiss 2013). Roberts (2002) raised concerns over the lack of 'quality' scientists in the UK; if science educators are keen to recruit the most capable personnel in science, then policymakers ought to identify ways to ensure careers in science are desirable among talented science students. Targeted intervention for these high achieving students could focus on and emphasise the underlying value of science and science-related careers.

Science prominent students have career aspirations toward science and high levels of achievement, interest and capital in science. Some science prominent students, at least in the current study, mentioned that their science career aspirations are medical-related. This is 
noteworthy as concerns over the 'leaky' science education pipeline is more likely to be rectified by an increase of young people with careers aspirations in science (e.g. to be scientists) rather than careers aspirations from science (e.g. to be doctors) (Wong, forthcoming). For instance, while minority ethnic students are all underrepresented in the study of physics at doctorate level in UK universities (Elias et al. 2006), they are generally overrepresented in the study of medicine and dentistry (HESA 2013). For some science prominent students, it seems that their study of, and achievement in, school science may merely be a stepping stone en route to their goal of a medical career. Thus, in science disciplines such as physics (e.g. at degree level and beyond), there may still be an underrepresentation of scientifically competent students from minority ethnic backgrounds. Further work is necessary to explore the views and aspirations of minority ethnic students toward different science disciplines.

This paper has sought to contribute to our knowledge base of minority ethnic students and the different ways in which they can participate in science. The five 'types' of science participations provide a lens for understanding the current and future pathways of students in science. This study cautions against a 'one-size-fit-all' approach towards the science education of minority ethnic students, given their experiences of science are evidently diverse. A multiple approach is suggested in order to address the needs of different students, which may build on, or respond to, the 'types' of science participations. Although the 'types' of science participation emerged from the study of minority ethnic students, the characteristics of these 'types' are not specific to minority ethnic students or groups. Findings from this paper may provide a useful platform for investigating the science participations of students across a wider population.

\section{Acknowledgments}

The author would like to thank Marie-Pierre Moreau for her comments on an earlier draft of this paper. This work was supported by the ESRC under Grant ES/H005072/1 and RES-17925-0008, and the Rosalind Driver Scholarship Fund at King's College London.

\section{Reference}

ACOLA. (2013). STEM: Country Comparisons. Melbourne: Australian Council of Learned Academies (ACOLA).

Adamuti-Trachea, M., \& Sweet, R. (2014). Science, Technology, Engineering and Math Readiness: Ethno-linguistic and gender differences in high-school course selection patterns. International Journal of Science Education, 36(4), 610-634.

Ainley, M., \& Ainley, J. (2011). Student engagement with science in early adolescence: The contribution of enjoyment to students' continuing interest in learning about science. Contemporary Educational Psychology, 36, 4-12.

Archer, L., \& Francis, B. (2007). Understanding minority ethnic achievement. London: Routledge.

Archer, L. DeWitt, J., \& Willis, B. (2014a). Adolescent boys' science aspirations: Masculinity, capital, and power. Journal of Research in Science Teaching, 51(1), 1-30.

Archer. L., DeWitt, J., \& Wong, B (2014b). Spheres of Influence: What shapes young people's aspirations at age $12 / 13$ and what are the implications for education policy? Journal of Education Policy, 29(1), 58-85.

Archer, L., DeWitt, J., Osborne, J., Dillon, J., Willis, B., \& Wong, B. (2010). 'Doing' science vs 'being' a scientist: examining 10/11 year old school children's constructions of science through the lens of identity. Science Education, 94(4), 617-639. 
Archer, L., DeWitt, J., Osborne, J., Dillon, J., Willis, B., \& Wong, B. (2012) Science Aspirations and family habitus: How families shape children's engagement and identification with science. American Education Research Journal, 49(5), 881-908.

Archer, L., Osborne, J., DeWitt, J., Dillon, J., Wong, B., \& Willis, B. (2013). ASPIRES: Young people's science and career aspirations, age 10-14. London: King's College London.

Aschbacher, P. R., Li, E., \& Roth, E. J. (2010). Is Science Me? High School Students' Identities, Participation and Aspirations in Science, Engineering and Medicine. Journal of Research in Science Teaching, 47(5), 564-582.

Bennett, J., \& Hogarth, S. (2009). Would you want to talk to a scientist at a party? High school students' attitudes to school science and to science. International Journal of Science Education, 31(14), 1975-1998.

Blickenstaff, J. C. (2005). Women and science careers: Leaky pipeline or gender filter? Gender and Education, 17(4), 369-386.

Brickhouse, N. W., \& Potter, J. T. (2001). Young women's scientific identity formation in an urban context. Journal of Research in Science Teaching, 37(8), 965-980.

Brickhouse, N. W., Lowery, P., \& Schultz, K. (2000). What kind of a girl does science? The construction of school science identities. Journal of Research in Science Teaching, 37(5), 441-458.

Brotman, J. S., \& Moore, F. M. (2008). Girls and science: A review of four themes in the science education literature. Journal of Research in Science Teaching, 45(9), 971-1002.

Carlone, H. B., \& Johnson, A. C. (2007). Understanding the science experiences of women of color: Science identity as an analytic lens. Journal of Research in Science Teaching, 44(8), $1187-1218$.

CBI. 2012. Learning to Grow: What Employers Need from Education and Skills. Education and skills survey 2012. London: Confederation for British Industry.

Ceci, S. J., \& Williams, W. M. (2007). Why aren't more women in science? Top researchers debate the evidence. Washington, DC: American Psychological Association.

Chang, M. J., Sharkness, J., Hurtado, S., \& Newman, C. B. (2014). What Matters in College for Retaining Aspiring Scientists and Engineers From Underrepresented Racial Groups. Journal of Research in Science Teaching, doi: 10.1002/tea.21146

Cole, D., \& Espinoza, A. (2008). Examining the academic success of Latino students in science, technology, engineering, and mathematics (STEM) majors. Journal of College Student Development, 49(4), 285-300.

Crozier, G. (2009). South Asian parents' aspirations versus teachers' expectations in the United Kingdom. Theory Into Practice, 48(4), 290-296.

DeWitt, J., Archer, L., \& Osborne, J. (2013). Nerdy, brainy and normal: Children's and parents' constructions of those who are highly engaged with science. Research in Science Education, 43(4), 1455-1476.

DeWitt, J., Archer, L., Osborne, J., Dillon, J., Willis, B., \& Wong, B. (2011). High Aspirations but Low Progression: The science aspirations-careers paradox among minority ethnic students. International Journal for Science and Mathematics Education, 9(2), 243-271.

DfE. (2010). National Curriculum Assessments at Key Stage 2 \& 3 in England, 2009/10 (Provisional). SFR 23/2010. London: Department for Education.

DIUS. (2009). The Demand for Science, Technology, Engineering and Mathematics (STEM) Skills. URN 168-09-SC-on. London: Department for Innovation, Universities and Skills.

Elias, P., Jones, P., \& McWhinnie, S. (2006). Representation of ethnic groups in chemistry and physics: A report prepared for the Royal Society of Chemistry and the Institute of Physics. London: Royal Society of Chemistry/IOP.

EngineeringUK. (2014). Engineering UK 2014: The state of engineering. EngineeringUK 
Gillborn, D. (2008). Racism and education: Coincidence or conspiracy? London: Routledge.

Gungor, A., Eryılmaz, A., \& Fakıoglu, T. (2007). The relationship of freshmen's physics achievement and their related affective characteristics. Journal of Research in Science Teaching, 44(8), 1036-1056.

HESA (2013). Table 13 - UK domiciled HE students by level of study, gender, mode of study, first year identifier and ethnicity 2011/12. http://www.hesa.ac.uk/dox/dataTables/studentsAndQualifiers/download/ethnic1112.xls. Accessed 24 March 2014.

Ho, E. S. C. (2010). Family influences on science learning among Hong Kong adolescents: What we learned from PISA. International Journal of Science and Mathematics Education, 8(3), 409-428.

House of Lords. (2012). Higher Education in Science, Technology, Engineering and Mathematics (STEM) subjects. London: The Stationery Office Limited.

HM Treasury. (2011). The plan for growth. London: BIS.

Jenkins, E. W., \& Nelson, N. W. (2005). Important but not for me: Students' attitudes towards secondary school science in England. Research in Science \& Technological Education, 23(1), 41-57.

Jivraj, S. (2012). How has ethnic diversity grown 1991-2001-2011?. The University of Manchester: ESRC Centre on Dynamics of Ethnicity (CoDE).

Losh, S. C. (2010). Stereotypes about scientists over time among US adults: 1983 and 2001. Public Understanding of Science, 19(3), 372-382.

Lyons, T. (2006). The puzzle of falling enrolments in physics and chemistry courses: Putting some pieces together. Research in Science Education, 36(3), 285-311.

Marlone, K. R., \& Barabino, G. (2009). Narrations of race in STEM research settings: Identity formation and its discontents. Science Education, 93(3), 485-510.

Masnick, A. M., Valenti, S. S., Cox, B. D., \& Osman, C. J. (2010). A multidimensional scaling analysis of students' attitudes about science careers. International Journal of Science Education, 32(5), 653-667.

Mendick, H., \& Moreau, M.P. (2013). New Media, Old Images: Constructing online representations of women and men in science, engineering and technology. Gender \& Education, 25(3): 325-339.

Miles, M. B., \& Huberman, A. M. (1994). Qualitative data analysis. $2^{\text {nd }}$ Edition. Thousand Oaks, CA: SAGE.

Mujtaba, T., \& Reiss, M. J. (2013). A survey of psychological, motivational, family and perceptions of physics education factors that explain 15-year-old students' aspirations to study physics in post-compulsory English schools. International Journal of Science and Mathematics Education, doi: 10.1007/s10763-013-9404-1

National Academy of Sciences. (2005). Rising above the gathering storm: energizing and employing America for a brighter economic future. Washington, DC: National Academy of Sciences.

Ong, M. (2005). Body projects of young women of color in physics: Intersections of gender, race, and science. Social Problems, 52(4), 593-617.

Osborne, J. (2008). Engaging young people with science: Does science education need a new vision? School Science Review, 89(328), 67-74.

Osborne, J., \& Dillon, J. (2008). Science education in Europe: Critical reflections. London: Nuffield Foundation.

Oxford Dictionaries. (2010). Oxford dictionary of English. $3^{\text {rd }}$ Edition. Oxford: Oxford University Press. 
Riegle-Crumb, C., Moore, C., \& Ramos-Wada, A. (2011). Who wants to have a career in science and maths? Exploring adolescents' future aspirations by gender and race/ethnicity. Science Education, 95(3), 458-476.

Roberts, G. (2002). SET for success: The supply of people with science, technology, engineering and mathematics skills. London: HM Treasury.

Royal Society. (2014). A picture of the UK scientific workforce. London: Royal Society.

Schreiner, C., \& Sjøberg, S. (2007). Science education and youth's identity construction two incompatible projects? In D. Corrigan, J. Dillon., \& R. Gunstone (Eds.) The reemergence of values in the science curriculum (pp. 231-248). Rotterdam: Sense Publishers.

Smith, E. (2011). Women into science and engineering? Gendered participation in higher education STEM subjects. British Educational Research Journal, 37(6), 993-1014.

St Clair, R., \& Benjamin, A. (2011). Performing desires: The dilemma of aspirations and educational attainment. British Educational Research Journal, 37(3), 501-517.

Tai, R. H., Qi Liu, C., Maltese, A. V., \& Fan, X. (2006). Planning early for careers in science. Science, 312(5777), 1143-1145.

Tan, E., \& Calabrese Barton, A. (2010). Transforming science learning and student participation in sixth grade science: A case study of a low-income, urban, racial minority classroom. Equity \& Excellence in Education, 43(1), 38-55.

Wong, B. (2012). Identifying with science: A case study of two 13 year-old British Asian 'high achieving working class' schoolgirls. International Journal of Science Education, 34(1), 43-65.

Wong, B. (Forthcoming). Careers 'from' but not 'in' science: Why aspirations to be a scientist are challenging for minority ethnic students? Journal of Research in Science Teaching

US Census Bureau (2011) STEM, STEM-related, and Non-STEM Occupation Code List 2010. Accessed $25^{\text {th }}$ September 2014. URL:

https://www.census.gov/people/io/files/STEM-Census-2010-occ-code-list.xls 